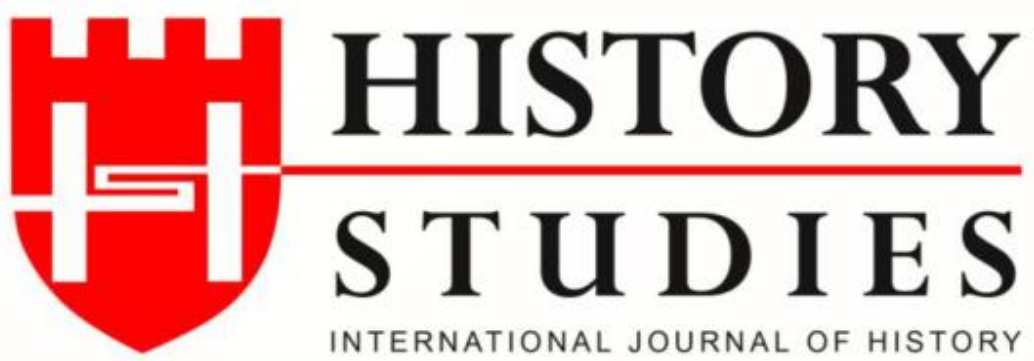

ISSN: 13094173 (Online) 1309 - 4688 (Print)

Volume 10 Issue 10, A Tribute to Prof. Dr. Yilmaz KURT, p. 119-129, December 2018

DOI Number: 10.9737/hist.2018.694

\title{
Cumhuriyet Döneminde Adalet Alanında Meydana Gelen Gelişmeler (1923-1950)
}

The Development In Justice During the Republic Period (1923-1950)

\author{
Prof. Dr. Mehmet EVSİLE \\ (ORCID: 0000-0001-5289-8703) \\ Amasya Üniversitesi
}

\begin{abstract}
Öz: Türkiye Cumhuriyeti'nin ilânından sonra her alanda olduğu gibi, hukuk alanında da yeni düzenlemeler yapılmıştır. Bu çerçevede Türk Medenî Kanunu, Türk Ceza Kanunu, Türk Ticaret Kanunu, Hukuk Muhakemeleri Usûlü Kanunu, Ceza Muhakemeleri Usûlü Kanunu, İcra ve İflâs Kanunu, Deniz Ticareti Kanunu çıkartılmıştır. Bu düzenlemelerin sonucunda "Hukuk Devleti"ne geçilmiştir. Bu çerçevede yeni bir adliye teşkilâtı kurulmuş, yeni mahkemeler açılmış, yeni personel yetiş̧irilmiş ve yeni bir adalet sistemi oluşturulmuş̧ur. Zihniyet olarak halkın hükümetten "adalet dilenmesi" şeklindeki anlayıştan, "hükümetler, halkın mal, hayat ve namusunu korumak için teşekkül etmiştir" anlayışına geçilmesi sağlanmıştır. Kadastro çalışmaları ile toprak anlaşmazlıklarından doğan olayların sayısı azaltılmıştır. Adliye hizmetlerinde özellikle maddî ve fizikî imkânsızlıklar yüzünden bazı problemler yaşanmışsa da, cumhuriyet idaresi zaman içerisinde bu sıkıntıları en alt seviyelere çekmeye çalışmıştır.
\end{abstract}

Anahtar Kelimeler: Türkiye Cumhuriyeti, Hukuk İnklâbı, Adalet Sistemi, Adliye Personeli, Mahkeme ve Mahkûmlar, Kadastro Çalışmaları.

\begin{abstract}
After the decleration of Turkish Republic, there have been many changes and new regulations in justice as well as in all aspects of the country. In this context, New laws such as in the field of Turkish Civil Code, Turkish Penal Code, Turkish Trade Code, Turkish Civil Justice Code, Turkish Penal Justice Code, Turkish Bankrupcy Cases Code and Sea Trade Code were put into power. After these regulations, Turkey has been known as a country of "State of Law". A new court system was established. New courts started to give justice, New trained staff was employed. A new approach appeared in the court in which the State was established to protect the lives, honor and the property of the people. Land conflicts among people became less through the laws made in the field of cadastral survey. Although there have seen some problems because of the physical and financial in sufficiencies, in following years the State has tried to solve all these obstacles and to minimize them.
\end{abstract}

Keywords: Turkish Republic, Justice Revolution, Justice System, Courts and Convicted People, Court Staff, Cadastral Studies.

\section{Giriş}

Türkiye Cumhuriyeti'nin ilânından sonra her alanda olduğu gibi, hukuk alanında da yeni düzenlemeler yapılmıştır. 17 Şubat 1926'da Türk Medenî Kanunu, 1 Mart 1926'da Türk Ceza Kanunu, 29 Mayıs 1926'da Türk Ticaret Kanunu, 18 Haziran 1926'da Hukuk Muhakemeleri 
Usûlü Kanunu, 4 Nisan 1929'da Ceza muhakemeleri Usûlü Kanunu, Nisan 1929'da İcra ve İflâs Kanunu, 13 Mayıs 1929'da Deniz Ticareti Kanunu çıkartılmıştır' ${ }^{1}$.

Bu düzenlemelerin sonucunda "Hukuk Devleti”ne geçilmiştir. Devlet, vatandaşlar gibi ve onlar kadar hukuka saygılı ve hukuka bağlı hale gelmiştir. Vatandaşın bu konudaki güvencesi kanunlarla sağlanmıştır. Hukuk inkılâbıyla Türkiye Cumhuriyeti, bağımsız ve egemen bir devletin en doğal hakkı olan yargı gücünü de güvence altına almıştır. Türk halkının sosyal hayatı çağdaş seviyeye çıkartılmış, gelişiminin önündeki engeller yıkıımıştır ${ }^{2}$.

Yapılan düzenlemeler çerçevesinde yeni bir adliye teşkilâtı kurulmuş, yeni mahkemeler açılmış, yeni personel yetiştirilmiş ve yeni bir adalet sistemi oluşturulmuştur. Türkiye Büyük Millet Meclisi bütçe görüşmelerinde dile getirilen ifadelerden aldığımız bilgilerle, bu sistemin günlük hayata yansımaları takip edilecektir.

\section{1-Adliye Teşkilâtının Kuruluşu}

Türkiye Büyük Millet Meclisi'nin açılışından sonra, 2 Mayıs 1920 tarihinde kabul edilen 3 numaralı "Büyük Millet Meclisi İcra Vekillerinin suret-i intihabına dair kanun"un birinci maddesi ile "Adliye ve Mezahip Vekâleti" adı ile bugünkü Adalet Bakanlı̆̆ı'nın temelleri atılmıştır ${ }^{3}$.

Birinci İcra Vekilleri Hey’eti’nin 9 Mayıs 1920 tarihinde Türkiye Büyük Millet Meclisi'ne sunduğu programında, adliye teşkilâtının iki temel probleminden bahsedilmiştir. Bunlardan birincisi, adalet hizmeti verecek hakim ve memur sayılarının çok düşük oluşudur. Hükümet, bu personelin maaşlarını yükseltmek suretiyle sayılarını artırmayı vaad etmiştir. İkinci olarak da halkın hükümetten "adalet dilenmesi" şeklindeki mevcut anlayışın, "hükümetler, halkın mal, hayat ve namusunu korumak için teşekkül etmiştir" anlayışına çevrilmesi gerektiği ifade edilmiştir ${ }^{4}$.

\section{2-Mahkemeler}

Adalet bakanları tarafından zaman zaman ülke sathındaki mahkemeler hakkında bilgiler verilmiştir. Buna göre 1924 y1lında 85'i şehir ve kasabalarda, 14'ü nahiyelerde olmak üzere 99 sulh mahkemesi, 1925 yılında 85'i şehirlerde, 57'si nahiyelerde olmak üzere 142 sulh mahkemesi, 1926 yılında 105'i şehirlerde, 90'ı nahiyelerde olmak üzere 195 sulh mahkemesi, 1927 y1lında 136'sı şehir ve kasabalarda, 99'u nahiyelerde olmak üzere 235 sulh mahkemesi bulunmaktadır. Ayrıca 1927 yılında diğer mahkemelerle birlikte 742 mahkeme, 1877 hakim, 1971 kâtip ve 1091 mübaşirle toplam 1.250 .000 dosya üzerinde işlem yapılmıştır. 1928 yılında toplam mahkeme sayısı 792, hakim sayısı 1951, kâtip sayısı 2217, mübaşir sayısı da 1022 olmuştur ${ }^{5}$.

1944-1945 y1llarında 46 il ve ilçede yeni mahkemeler kurulmuş veya mevcut teşkilât güçlendirilmiştir. 23 ilçede sulh mahkemeleri, 6 ilçede asliye mahkemeleri kurulmuş; 3 ilçede sulh mahkemeleri asliyeye çevrilmiştir. 4 ilçede çift yargıçlı asliye mahkemeleri kurulmuş, 2 ilçede ağır ceza mahkemesi kurulmuştur. 8 yerde mevcut mahkemelere ilâveler yapılmıştır 6 .

\footnotetext{
${ }^{1}$ Atatürk ve Türkiye Cumhuriyeti Tarihi (Editör:M. Derviş KILIÇKAYA), Siyasal Kitabevi, Ankara, 2005, s.307-309.

${ }^{2}$ Türkiye Cumhuriyeti Tarihi II, Atatürk Araştırma Merkezi Yayını, Ankara, 2004, s.83-84.

${ }^{3}$ 02.05.1920, TBMM, TBMM ZC (1.Dönem), Cilt: 1, s.185.

${ }^{4}$ Hükümetler ve Programları I.Cilt 1920-1960, Türkiye Büyük Millet Meclisi Yayını, Ankara, 1988, s. 4-5.

${ }^{5}$ Adliye Vekili Mahmut Esat Bey (İzmir); 24.04.1928, TBMM, TBMM ZC (3.Dönem), Cilt: 3, s.227.

${ }^{6}$ Adalet Bakanı Ali Rıza TÜREL (Konya); 20.12.1945, TBMM, TBMM TD (7.Dönem), Cilt:20, s.218.
} 
Buna rağmen ülkenin bazı bölgelerinde sıkıntılar yaşanmıştır. 1949 yılında, 436 kazadan 11 'sinde asliye mahkemesi teşkilâtı olmadığ ${ }^{7}, 1950$ yılında 109 ilçenin mahkemesiz olduğu dile getirilmiştir ${ }^{8}$. Bu konuya bir örnek olarak, yeni ilçe yapılan Kütahya-Altıntaş'taki durum da şöyle anlatılmıştır' :"Iki sene evvel Kütahya ilinde Altıntaş kazası diye bir kaza teşkil edildi. Bu kazada halen savc1, icra memuru, noter yoktur. Yalnız bir tek hakim vardır. Kazanın 52 köyü bulunmaktadır (20 binden fazla nüfusu vardır), cezaevi de yoktur. Cezaevi bir köy damında, adalet dairesi de bir köy mektebinin bodrum katının iki odasında yerleşmiştir." Bununla birlikte başka yerlerden de mevcut mahkeme binalarının bakımsız ve yetersiz oluşu ${ }^{10}$, mefruşat ve isıtma konularında yaşanan sıkıntılar dile getirilmiştir ${ }^{11}$.

3 Aralık 1933 yılında yanan İstanbul Sultanahmet Adliye Sarayı, 1950 yılına kadar hâlâ yeniden yapılıp hizmete girmediği için İstanbul bir adliye mekânına hasret kalmıştır ${ }^{12}$. Yeni yapılan bina ancak 1955 yılında açılmıştır. Diyarbakır Adliye binası da 1946 yılında yandığı için adalet hizmetlerinin uygun olmayan yerlerde yapıldığından şikâyet edilmiştir ${ }^{13}$.

Mahkemelerin iş yükü hakkındaki bilgiler de şöyledir:

1935 yilında mahkemelere arzedilen 357.205 ceza davasından 264.771 adedi sonuçlandırılmış, 92.434'ü 1936 yılına devredilmiştir ${ }^{14}$.

1946 yılında Ağır Ceza Mahkemelerine 24.698, Asliye Ceza Mahkemelerine 214.118,

Sulh Ceza Mahkemelerine 511.263, Asliye Hukuk Mahkemelerine 282.890, Sulh Hukuk Mahkemelerine 210.297, Ticaret Mahkemelerine 501.946, Sorgu yargıçlıklarına 29.388, İcra Dairelerine 368.212 iş olmak üzere mahkeme ve icra dairelerine bir yıl zarfında gelen iş miktarı 1.410 .809 olmuştur $^{15}$. Yargıtay'a yılda ortalama 110.000 iş gelmekte ve bunların 100.000'i karara bağlanmaktadır ${ }^{16}$. Ayrıca kaçakçılık olaylarını değerlendirmek üzere ihtisas mahkemeleri de kurulmuştur ${ }^{17}$. Çiftçi mallarının korunması ve ziraî asayişin sağlanması için köylerde seyyar sulh hakimleri tesis edilmek istenmiş ama mümkün olmamıştır ${ }^{18}$. Bunun sonucu olarak hayvan hırsızlığı davaları, ilgili mahkemelerin iş yoğunluğunu çok artırmıştır ${ }^{19}$.

İkinci Dünya savaşı sırasında ülkenin önceliklerinin başka alanlara kaydırılması üzerine adalet hizmetlerinin geliştirilmesinde bazı sıkıntılar yaşanmıştır ${ }^{20}$. Bazı davaların uzun yıllar (10-15 sene) sonuçlanmamış olması ${ }^{21}$ ve adliye personelinin özlük haklarının Adalet Bakanının elinde olması dolayısıyla adliyenin istiklâlinin zedelendiği hususları da eleştirilmiştir ${ }^{22}$.

\footnotetext{
${ }^{7}$ Feridun Fikri DÜŞÜNSEL (Bingöl); 23.02.1949, TBMM, TBMM TD (8.Dönem), Cilt:16, s.484.

${ }^{8}$ Fuat Hulûsi DEMİRELLİ (İstanbul); 14.02.1950, TBMM, TBMM TD (8.Dönem), Cilt:24, s.561.

${ }^{9}$ Ahmet VEZİROĞLU (Afyonkarahisar); 22.02.1949, TBMM, TBMM TD (8.Dönem), Cilt:16, s.490.

${ }^{10}$ Mehmet Kâzım BERKER (Urfa); 25.05.1943, TBMM, TBMM ZC (7.Dönem), Cilt: 2, s.221.

${ }^{11}$ Kılıçoğlu Hakkı Bey (Kocaeli); 24.04.1928, TBMM, TBMM ZC (3.Dönem), Cilt: 3, s.230.

${ }^{12}$ Fuat Hulûsi DEMİRELLİ (İstanbul); 14.02.1950, TBMM, TBMM TD (8.Dönem), Cilt:24, s.560.

${ }^{13}$ Feyzi KALFAGIL (Diyarbakır); 27.12.1947, TBMM, TBMM TD (8.Dönem), Cilt:8, s.441.

${ }_{14}^{14}$ Adliye Vekili Şükrü SARAÇOĞLU (İzmir); 26.54.1936, TBMM, TBMM ZC (5.Dönem), Cilt:11, s.233.

${ }^{15}$ Adalet Bakanı Şinasi DEVRİN (Zonguldak); 27.12.1947, TBMM, TBMM TD (8.Dönem), Cilt:8, s.458.

${ }^{16}$ Mahmut Kemâl BORAN (Mardin); 14.02.1950, TBMM, TBMM TD (8.Dönem), Cilt:24, s.566.

${ }^{17}$ Adliye Vekili Yusuf Kemâl Bey (Sinop); 22.06.1932, TBMM, TBMM ZC (4.Dönem), Cilt:9, s.260-261.

${ }^{18}$ Abidin BİNKAYA (Kastamonu); 27.05.1941, TBMM, TBMM ZC (6.Dönem), Cilt:18, s.207.

${ }^{19}$ Hasene ILGAZ (Çorum); 14.02.1950, TBMM, TBMM TD (8.Dönem), Cilt:24, s.571.

${ }^{20}$ Adalet Bakanı Ali Rıza TÜREL (Konya); 20.12.1945, TBMM, TBMM TD (7.Dönem), Cilt:20, s.216

${ }^{21}$ Sinan TEKELİOĞLU (Seyhan); 23.02.1949, TBMM, TBMM TD (8.Dönem), Cilt:16, s.483.

${ }^{22}$ Osman Nuri KÖNİ (İstanbul); 23.02.1943, TBMM, TBMM TD (8.Dönem), Cilt:16, s.455.
} 


\section{3-Cezaevleri}

Cumhuriyetin devraldığı cezaevlerinin durumu ve bu konuda yapılması gereken düzenlemeler de dile getirilmiştir. İzmir milletvekili Şükrü SARACOĞLU, bakan olmadan önce ve bakanlığ 1 sırasında bu konularla ilgilenmiş ve gördüklerini anlatmıştır. 1924 yılında ilk ifadesi şu şekilde olmuştur 23: "Bendenizin doğduğum büyüdüğüm yerlerin ahalisi nasılsa hapishaneleri biraz fazla ziyaret ediyorlar. Kendilerini görmeye gitmiştim. Hapishanede bana dediler ki: Biz buraya carih olarak, katil olarak geliyoruz, birkaç sene yattıktan sonra çıkarken yalnız katil, carih değil, birer dolandırıcı, hırsız, kumarbaz, ahlâksız birer adam olarak çıkıyoruz dediler... Eğer hapishaneler bu halde devam edecekse, bence hapishaneler bu cemiyete müfit birer müessese olmaktan ziyade bu muhit asayişi için daima muzir, daima fena adamlar yetiştiren birer mektep olarak kalacaktır.” Şükrü SARACOĞLU, 1936 yılında Adalet Bakanı olarak cezaevlerinin durumunun iyi olmadığını şu sözlerle ifade etmiştir ${ }^{24}$ : “...cezaevlerinin bugünkü hali esaslı kaygılarımızdan birini teşkil etmektedir. Eski devrede derin bir mazhariyetsizlik içinde kalan ceza müesseselerinin bize intikal eden binaları, en ibtidaî sıhhiyeden mahrum ve hemen hepsi bugünkü prensip ve telâkkilere göre ceza infazına müsait olmayan yerlerdir. Bunlardan birçoklarının mevcudu istiap kabiliyetlerinin kat kat üstündedir. Bazılarında her mahkûma isabet eden yer bir metre kareyi bile bulmamaktadır. Hapishane binalarının bu vaziyeti mahkûmlardan kabil-i 1slah olanlarının olmayanlardan tefrikini ve hattâ bir kısım yerlerde çocuk mahkûmların bile büyüklerden ayrılmasını imkânsız kılmıştır. Bu hapishanelerin idaresi devlete her sene 900.000 liralık bir yük tahmil etmektedir. Bunun 600.000 liradan fazlası bir ekmek tedarikinden bile aciz olduğu sabit olanlara verilmekte olan kuru ekmek bedelidir. Bundan başka diğer mahkûmlara aileleri tarafindan elbise, yatak, yemek için yapılmakta olan yardımın, mahkûm başına 20 kuruş hesabı ile, senede 2,5 milyon liraya baliğ olduğunu düşünürsek ne müthiş bir istihlâk (tüketim) makinesi ile karşı karşıya bulunduğumuz anlaş1ır. Bu vaziyette güneş ve temiz havadan, kâfi gıdadan mahrum bulunan ve hemen tamamen denilecek derecede uyuşuk bir hayat geçirmekte olan bu insan kitlesini sslah ve terbiye ve bir daha cürüm işlemekten sakınacak bir hale getirmeye matuf emellerin ve ne çetin ve devamlı bir mesaiyi iltizam edeceği kendiliğinden tezahür eder."

Cezaevlerinin yetersiz oluşu ${ }^{25}$ ve 1 slah edilmeleri gerektiği daha sonraki yıllarda da dile getirilmiştir $^{26}$. Tokat'ta, hükümet binasının alt katında ırmak üzerine kalaslar döşenerek oluşturulan bir bölümün cezaevi olarak kullanıldı $\breve{g}_{1}^{27}$; Kayseri'de bir Ermeni kilisesinin ${ }^{28}$, Kırşehir Mucur'da eski bir cami ${ }^{29}$ ve Hakkâri'de Selçuklu devrinden kalma Meydan Camiinin cezaevi olarak kullanıldığı bölge milletvekilleri tarafından ifade edilmiştir ${ }^{30}$.

1945 y1lında ülke sathında 467 adet cezaevinin çoğunluğunun elverişsiz binalarda hizmet verdiği Adalet Bakanı Ali Rıza TÜREL ${ }^{31} ; 1946$ yılında, 470 cezaevinden 370 adedinin yeniden inşa edilmek mecburiyetinde olduğu, o günün Adalet Bakanı Şinasi DEVRİN tarafından dile getirilmiştir ${ }^{32}$.

${ }^{23}$ Saracoğlu Şükrü Bey (İzmir); 25.02.1924, TBMM, TBMM ZC (2.Dönem), Cilt:6, s.333.

${ }^{24}$ Adliye Vekili Sükrü SARACOĞLU (İzmir); 26.05.1936, TBMM, TBMM ZC (5.Dönem), Cilt:11, s.234.

${ }^{25}$ İstamat ÖZDAMAR (Eskişehir); 25.05.1937, TBMM, TBMM ZC (5.Dönem), Cilt:18, s.232.

${ }^{26}$ Berç TÜRKER (Afyonkarahisar); 25.05.1937, TBMM, TBMM ZC (5.Dönem), Cilt:18, s.239.

${ }^{27}$ Sabri ÇELIKKOL (Tokat); 20.12.1945, TBMM, TBMM TD (7.Dönem), Cilt:20, s.227.

${ }^{28}$ Faik SEZER (Kurşehir); 20.02.1945, TBMM, TBMM TD (7.Dönem), Cilt:20, s.229.

${ }^{29}$ Faik SEZER (Kırşehir); 20.02.1945, TBMM, TBMM TD (7.Dönem), Cilt:20, s.228.

${ }^{30}$ İbrahim ARVAS (Van); 14.02.1950, TBMM, TBMM TD (8.Dönem), Cilt:24, s.572.

${ }^{31}$ Adalet Bakanı Ali Riza TÜREL (Konya); 22.05.1945, TBMM, TBMM TD (7.Dönem), Cilt:17, s.273.

${ }^{32}$ Adalet Bakanı Şinasi DEVRİN (Zonguldak); 19.12.1946, TBMM, TBMM TD (8.Dönem), Cilt:3, s.303. 
Tutukluların, mahkûmlarla aynı yerlerde kalmalarının uygun olmadığı eleştirilmiştir ${ }^{33}$. Cezaevlerinin asayişinin sağlanmasında sıkıntılar yaşandığı, bıçak, rakı, esrar ve kokain gibi maddelerin cezaevine sokulduğu görülmüştür ${ }^{34}$. Cezaevlerinden çıkanların da iş bulmakta sıkıntı çektikleri ve bu problemlere çözüm getirilmesi istenmiştir ${ }^{35}$.

$\mathrm{Bu}$ sıkıntıları ortadan kaldırmak üzere cezaevi sisteminde değişiklikler yapılarak yeni cezaevleri inşa edilmiştir. Bunlar, iş esası üzerine kurulmuş, döner sermaye ile çalışan, mahkûmları çalıştırma ve islah etme amaciyla kurulmuştur. Bu sistemle, tesadüfen veyahut itiyadî olarak suç işlemiş adamları ıslah ederek geri göndermek ve memlekete kazandırmak suretiyle manevî bir fayda temin etmek mümkün olduğu gibi; bunların emeklerini k1ymetlendirerek devlete yük olmaktan kurtarmak da söz konusu olacaktır ${ }^{36}$. Böylece 1949 yılına gelindiğinde 17-19 bin civarındaki mahkûmun 5400'ü yeni cezaevlerinde bulunmaktadır ${ }^{37}$. Yeni cezaevlerindeki mahkûmlar sıhhat şartları, gıda imkânları, iş ve kazanç temini ve günlerini kısaltma esasına göre ayarlanmış infaz dereceleri ve süresini tamamlamadan önce şartlı tahliyeyi mümkün kılan uygulamalardan faydalanmışlardır ${ }^{38} .1950$ y1lına gelindiğinde ise, toplam 19.000 mahkûmdan 6.000'inin yeni cezaevlerinde bulunduğu ifade edilmiştî ${ }^{39}$. Hattâ bazı işsiz vatandaşların geçimlerini sağlamak için yeni cezaevlerine girmek istedikleri görülmüştür. Böylece hiç değilse amele sıfatını kazanıyor ve dönerken de 1000, 1500 lira gibi kendince önemli bir para kazanmış oldukları tespit edilmiştir ${ }^{40}$.

10-11 yaşlarındaki çocuklar için Ankara Kalaba'da bir Çocuk Islah Evi açılmış ve buradaki çocuklara hapishane hayatından çok bir okul hayatı getirilmiştir. 15-18 yaşlarındaki suçlu çocuklar için de Sinop, Konya, İzmir ve Adana'da Çocuk Cezaevleri açılarak, çocuk mahkûmlar, büyüklerden ayrılmıştır. Ancak 1950 yılı itibarıyla ülkede toplam 1124 çocuk mahkûmdan ancak 342'si bu tesislerde kalmaktadır ${ }^{41}$.

\section{4-Mahkûmlar}

Cezaevlerindeki mahkûm sayıları hakkındaki bilgiler şöyledir: 1927 yılında 10.000'e yakın mahkûm bulunurken ${ }^{42}, 1938$ yılında 35.000'e yaklaşmış, Af kanunu ile bu rakam 23-24 bine düşmüştür ${ }^{43} .1941$ yılında $27.000^{44}, 1945$ yılında 30.000'e yaklaşmıştır ${ }^{45}$. Mahkûmların arasında ilk sırayı katiller almaktadır. 1938 yılında katl suçunu işleyenlerin ne kadarının hangi sebepten olduğu hakkındaki bir bilgi Adalet Bakanı tarafından şu şekilde paylaşılmıştı ${ }^{46}: 1913$ kan, kin, intikam, 1938 arazi, hudut ve su anlaşmazlıkları ve alacak davaları, 941 kız ve kadın kaçırmak, 784 hırsızlık, 784 fiil-i şen'î, 562 şekavet, 396 kaçakçılık, 377 sarhoşluk.

1945 y1lında, cezaevlerinde bulunan hükümlülere her gün ekmekten başka sıcak yemek, 75.000'den fazla çamaşır ve 11.000'e yakın kışlık ve yazlık elbise, 1350 ayakkabı

\footnotetext{
${ }^{33}$ Mehmet Kâzım BERKER (Urfa); 24.05.1944, TBMM, TBMM ZC (7.Dönem), Cilt:10, s.252.

${ }^{34}$ Hazim BOZCA (Afyonkarahisar); 23.02.1949, TBMM, TBMM TD (8.Dönem), Cilt: 16, s.461.

${ }^{35}$ Feridun Fikri DÜŞÜNSEL (Bingöl); 24.05.1944, TBMM, TBMM ZC (7.Dönem), Cilt:10, s.249-250.

${ }^{36}$ Adalet Bakanı Ali Rıza TÜREL (Konya); 22.05.1945, TBMM, TBMM TD (7.Dönem), Cilt:17, s.274.

${ }^{37}$ Adalet Bakanı Fuat SIRMEN (Rize); 23.02.1949, TBMM, TBMM TD (8.Dönem), Cilt:16, s.498.

${ }^{38}$ Hasan DİNÇER (Afyonkarahisar); 14.02.1950, TBMM, TBMM TD (8.Dönem), Cilt:24, s.565.

${ }^{39}$ Adalet Bakanı Fuat SİRMEN (Rize); 14.02.1950, TBMM, TBMM TD (8.Dönem), Cilt:24, s.590.

${ }^{40}$ Hazim BOZCA (Afyonkarahisar); 23.02.1949, TBMM, TBMM TD (8.Dönem), Cilt: 16, s.461.

${ }^{41}$ Adalet Bakanı Fuat SİRMEN (Rize); 14.02.1950, TBMM, TBMM TD (8.Dönem), Cilt:24, s.589.

${ }^{42}$ Adliye Vekili Mahmut Esat Bey (İzmir); 12.04.1927, TBMM, TBMM ZC (2.Dönem), Cilt: 31, s.80.

${ }^{43}$ Adliye Vekili Şükrü SARACOĞLU (İzmir); 24.05.1938, TBMM, TBMM ZC (5.Dönem), Cilt:25, s.176.

${ }^{44}$ Berç TÜRKER (Afyonkarahisar); 27.05.1941, TBMM, TBMM ZC (6.Dönem), Cilt:18, s.208.

${ }^{45}$ Adalet Bakanı Ali Riza TÜREL (Konya); 20.12.1945, TBMM, TBMM TD (7.Dönem), Cilt:20, s.220.

${ }^{46}$ Adliye Vekili Şükrü SARACOĞLU (İzmir); 24.05.1938, TBMM, TBMM ZC (5.Dönem), Cilt:25, s.176.
} 
dağıtılmıştır. Yerde yatmamaları için de 5.000'e yakın karyola kendi müesseselerinde yapılarak dağıtılmıştır ${ }^{47}$.

Cezaevlerinde çocuk mahkûmların büyüklerle aynı yerlerde bulunmasının mahzurlarına dikkat çekilerek, çocukların cezalarını çekecekleri yerler hazırlanması gerektiğine dikkat çekilmiştir ${ }^{48}$. Özellikle köylerden gelen çocuk mahkûmların cezaevlerinde sanat işlerinde çalıştırılmak suretiyle meslek edindirilerek tahliyelerinden sonra şehirlerde çalışarak yaşayacak hale getirildikleri de tespit edilmiştir ${ }^{49}$.

30 Mayıs 1942 tarihli Resmî Gazete'te yayınlanan kararnâme ile, kömür istihsalini memleketin ihtiyaçlarını temine kâfî̀ bir derecede bulundurmak gayesiyle Ereğli Kömür Havzası için Millî Korunma Kanunu'nun 9. Maddesine müsteniden ücretli iş mükellefiyeti tesis edilmiştir ${ }^{50}$. Bu kararnâme gereğince mahkûmların maden ocaklarında çalıştırılması talep edilmiştir ${ }^{5}$. Ancak bu kararnâme yayınlanmadan önce 1938 y1lında Zonguldak madenlerinde 350 mahkûmun çalıştığı bilinmektedir ${ }^{52}$. 1947 yılında ücretli iş mükellefiyetine uymayan 800 kişi 50 ilâ 100 lira arasında para, üç ay da hapis cezasına çarptırılmıştır ${ }^{53}$.

\section{5-Adalet Personeli}

1949 yılına gelindiğinde ülke sathında toplam 2400 hakim ve savcı bulunduğu görülmektedir ${ }^{54}$. Adalet personeli sayısındaki eksikliklerden dolayı pek çok problemler yaşanmıştır. Özellikle bazı ilçelerde tek hakimli mahkemelerde bulunan bir asliye hakimi, sulh hukuk, asliye hukuk, sulh ceza, asliye ceza, icra takibi, meşhut suçlar gibi konuların tamamına bakmaktadır. Ancak büyük şehirlerdeki mahkemelerde işbölümü vardır ${ }^{55}$. Bu durum, celselerin ilân edilen tarihlerde yapılmasına engel olduğu gibi, özellikle köylerden gelen vatandaşların mağduriyetine yol açmıştır ${ }^{56}$.

Hakimlerin özlük haklarında da bazı problemler vardır. 1947 yılında bir hakim maaşının 60 lira olduğu bilinmektedir ${ }^{57}$. Hakimlerin nakil ve atamalarında yaşanan sıkıntılar da dile getirilmiştir. Bazı hakimlerin mezun olur olmaz büyük şehirlere atanıp meslek hayatlarını oralarda geçirdikleri halde bazı hakimlerin mahrumiyet bölgelerinde meslek hayatlarını geçirmeleri eleştirilmiştir ${ }^{58}$. Normal zamanda bir hakimin 2 yılda bir terfi alması gerekirken bunun 3-4 y1lı bulduğu görülmüştür ${ }^{59}$. Tayin edildikleri yerlerde oturacak ev bulamayan hakimler, ailelerini yanlarına getirememişlerdir ${ }^{60}$. Bazı hakimler başlangıçta doğu illerine tayin olmuşlar ve meslek hayatlarının büyük bir bölümünü buralarda geçirmişler, batıya tayinleri çok geç zamanlarda yapılmıştır ${ }^{61}$. Çalıştıkları yerde ortaokul ve lise bulunmayan hakimlerin okul çağındaki çocukları da tahsillerini tamamlamak konusunda problemler yaşamışlardır ${ }^{62}$. $\mathrm{Bu}$ durumda bulunan özellikle Doğu Anadolu şehirlerinde çalışan hakimlerin çocuklarının

\footnotetext{
${ }^{47}$ Adalet Bakanı Ali Riza TÜREL (Konya); 20.12.1945, TBMM, TBMM TD (7.Dönem), Cilt:20, s.220.

${ }^{48}$ Adliye Vekili Şükrü SARACOĞLU (İzmir); 26.05.1936, TBMM, TBMM ZC (5.Dönem), Cilt:11, s.236.

${ }^{49}$ Adalet Bakanı Ali Rıza TÜREL (Konya); 25.05.1943, TBMM, TBMM ZC (7.Dönem), Cilt:2, s.226-227.

${ }^{50}$ Resmî Gazete, 30 May1s 1942, Say1:5119, s.2959-2960.

${ }^{51}$ Ali Rıza INNCEALEMDAROĞLU (Zonguldak); 27.12.1947, TBMM, TBMM TD (8.Dönem), Cilt:8, s.424.

${ }^{52}$ Adliye Vekili Şükrü SARACOĞLU (İzmir); 24.05.1938, TBMM, TBMM ZC (5.Dönem), Cilt:25, s.173.

${ }^{53}$ Ali Rıza İNCEALEMDAROĞLU (Zonguldak); 27.12.1947, TBMM, TBMM TD (8.Dönem), Cilt:8, s.423.

${ }^{54}$ Fuat Hulûsi DEMİRELLİ (İstanbul); 23.02.1949, TBMM, TBMM TD (8.Dönem), Cilt:16, s.456.

55 Abdullah YAYCIOĞLU (Maraş); 19.12.1946, TBMM, TBMM TD (8.Dönem), Cilt:3, s.300.

${ }^{56}$ Fethi MAĞGARA (Kastamonu); 26.12.1947, TBMM, TBMM TD (8.Dönem), Cilt:8, s.331.

${ }^{57}$ Feyzi KARAGİL (Diyarbakır); 27.12.1947, TBMM, TBMM TD (8.Dönem), Cilt:8, s.440.

${ }^{58}$ Hazim BOZCA (Afyonkarahisar); 23.02.1949, TBMM, TBMM TD (8.Dönem), Cilt: 16, s.459-460.

${ }^{59}$ Feyzullah USLU (Manisa); 25.05.1943, TBMM, TBMM ZC (7.Dönem), Cilt:2 s.224.

${ }^{60}$ Feridun Fikri DÜŞÜNSEL (Bingöl); 22.05.1945, TBMM, TBMM TD (7.Dönem), Cilt:17, s.267.

${ }^{61}$ Feyzi KALFAGILL (Diyarbakır); 27.12.1947, TBMM, TBMM TD (8.Dönem), Cilt:8, s.440.

${ }^{62}$ Akif ARKAN (Çankır1); 24.05.1944, TBMM, TBMM ZC (7.Dönem), Cilt:10, s.251.
} 
ikamet etmesi ve okullarına devam edebilmeleri için Ankara'da Adalet Bakanlığ tarafından bir pansiyon açılması talep edilmiştir ${ }^{63}$. Bununla birlikte Doğu Anadolu bölgesindeki şehirlerde yeterli sayıda hakim olmadığı için problemler yaşanmış, bunların aşılması için 3-4 yıllık mecburî hizmet uygulanması teklif edilmiştir ${ }^{64}$.

Hakimlere ekonomik destek sağlamak üzere bazı kanunî düzenlemeler de yapılmıştır.12 Haziran 1937 tarih ve 3253 sayılı "Çok çocuklu hakimlere yardım paraları ve ikramiye hakkında kanun" ile, 28 yaşını bitirip de birden, 30 yaşını bitirmiş olup da ikiden, 37 yaşını bitirmiş olup da üçten ve 42 yaşını bitirmiş bulunanlardan dörtten fazla çocuğu olanlara, fazla çocukların sayısına göre dağıtılacağı hükme bağlanmıştır ${ }^{65}$. Ancak bu uygulama istenilen sonuçları vermemiş ve hakimler arasında kargaşaya sebep olmuştur. Çünkü çocuk sahibi olmayan hakimlerin maaşlarından yapılacak kesintilerle çok çocuklu hakimlere yapılacak ödemelerin finanse edilmesi, çocuğu olmayanlar tarafından hoş karşılanmadığ ${ }_{1}^{66}$, bu haliyle anayasaya aykırı olduğu şeklinde değerlendirmeler yapılmıştır ${ }^{67}$. Daha sonra bu uygulama yürürlükten kaldırılmıştır ${ }^{68}$.

Hakim ve savcı atmalarında Adalet Bakanı'nın yetkili olması, hakim teminatını ortadan kaldıran bir husus olarak değerlendirilmiștir ${ }^{69}$. Hakimlere adalet dağıtmak yanında rejimi korumak $^{70}$ ve cumhuriyetin kanunlarının bekçisi olmak gibi görevler de yüklenmiştir ${ }^{71}$.

Avukatlık Kanunu'nun, avukatların problemlerini çözmekte yetersiz kaldığı görülmektedir. İleri yaşlara gelip, mesleğini yapamayan avukatların geçim sıkıntıları tespit edilmiş ve bunların ortadan kaldırılması için avukatların sosyal güvenliklerini sağlayacak tedbirlerin alınması istenmiştir. Her ne kadar avukatlar kendi aralarında bir yardımlaşma sandığ 1 oluşturarak, ölen meslektaşlarının defin işlerine yardım ediyorlarsa da bu yeterli görülmemiştir ${ }^{72}$. Stajyer avukatların da bir y1l avukat yanında bir yıl da mahkemelerde çalıştıkları süre içerisinde maaş alamadıkları için geçim sıkıntı içine girdikleri ifade edilmiştir $^{73}$. Başkâtip ve kâtiplerin maaşlarının yetersiz olduğu ${ }^{74}$; mübaşirlerin kadro sıkıntısı yaşadıkları ifade edilmiştir. Çünkü mübaşirlerin bir kısmı kadrolu, bir kısmı da ücretli olarak çalışmaktadırlar. Ücret karşılığı çalışanların kadroya geçme talepleri vardır. Ücretle çalışan 478 mübaşirin ancak ayda 15 lira geliri olduğu görülmektedir ${ }^{75}$. Adlî Tabipliklerin sayılarının artırılarak ülke sathına yayılması ve adlî tabiplere de hakim ve savcılara verilen ödeneklerin verilmesi talep edilmiştir ${ }^{76}$. Gardiyanlara da ailelerini geçindirecek seviyeden çok düşük maaş verildiği için uygun vasıflarda gardiyan bulunmasında sıkıntılar yaşandığı dile getirilmiştir ${ }^{77}$.

\footnotetext{
${ }^{63}$ Süleyman Sırrı İÇÖZ (Yozgat); 25.02.1945, TBMM, TBMM TD (7.Dönem), Cilt:17, s.270.

${ }^{64}$ Osman Nuri KÖNİ (İstanbul); 23.12.1949, TBMM, TBMM TD (8.Dönem), Cilt:16, s.454.

${ }^{65}$ Yaşar SEMIZ; “1923-1950 Döneminde Türkiye'de Nüfusu Arttırma Gayretleri ve Mecburî Evlendirme Kanunu (Bekârlık vergisi)", Selçuk Üniversitesi Türkiyat Araştırmaları Enstitüsü Dergisi, Sayı:27 (2010), s.423- 469, s.432.

${ }^{66}$ Kemâl ÖZÇOBAN (Afyonkarahisar); 27.15.1947, TBMM, TBMM TD (8.Dönem), Cilt:8, s.435.

${ }^{67}$ Sinan TEKELİĞLU (Seyhan); 19.12.1946, TBMM, TBMM TD (8.Dönem), Cilt:3, s.298.

${ }^{68}$ Osman Nuri KÖNİ (İstanbul); 23.12.1949, TBMM, TBMM TD (8.Dönem), Cilt:16, s.453.

${ }^{69}$ Osman Nuri KÖNİ (İstanbul); 27.12.1947, TBMM, TBMM TD (8.Dönem), Cilt:8, s.427.

${ }^{70}$ Kâmil COŞKUNOĞLU (Manisa); 19.12.1946, TBMM, TBMM TD (8.Dönem), Cilt:3, s.285.

${ }^{71}$ Behçet Kemâl ÇAĞLAR (Erzincan 19.12.1946, TBMM, TBMM TD (8.Dönem), Cilt:3, s.290.

${ }^{72}$ Salamon ADATO (İstanbul); 73.12.1947, TBMM, TBMM TD (8.Dönem), Cilt: 8, s.453.

${ }^{73}$ Salamon ADATO (İstanbul); 73.12.1947, TBMM, TBMM TD (8.Dönem), Cilt: 8, s.454.

${ }^{74}$ Feyzi KALFAGIL (Diyarbakır); 27.12.1947, TBMM, TBMM TD (8.Dönem), Cilt:8, s.441.

${ }^{75}$ Hasene ILGAZ (Çorum); 23.02.1949, TBMM, TBMM TD (8.Dönem), Cilt:16, s.477.

${ }^{76}$ Osman Nuri KÖNİ (İstanbul); 27.12.1947, TBMM, TBMM TD (8.Dönem), Cilt:8, s.426.

${ }^{77}$ Hasene ILGAZ (Çorum); 23.02.1949, TBMM, TBMM TD (8.Dönem), Cilt:16, s.477.
} 


\section{6-Kadastro Hizmetleri}

Osmanlı Devleti'nde ilk tapu kayıtları 1274 (1858) tarihli Arazi Kanunu ve Tapu Nizamnâmesi ve 1291 (1875) tarihli Emlâk Nizamnâmesi hükümleri dairesinde yapılan tahrirlerle oluşturulmuştur ${ }^{78}$. Ancak bu tahrirler, uzmanlar tarafından yapılmadığ 1 için bir sonuca ulaşamamıştır ${ }^{79}$. Daha sonra 1912 yılında yürürlüğe konulan "Emval-i gayrimenkulenin Tahdit ve Tahriri Hakkında Kanunu Muvakkat" adlı kanunla Konya'da kadastro planları yapılmışıır ${ }^{80}$.

Cumhuriyetin kuruluşundan sonra, 1924 yılında, Tapu Umum Müdürlüğü kurulmuş, 1925 yılında da peşpeşe iki kanun yürürlüğe konulmuştur. Bunlardan biri, 657 sayılı "Harita Müdüriyet-i Umumiyesi Kanunu"; diğeri de 658 sayıl "Kadastro Kanunu" dur ${ }^{81}$. Bu kanunlar ile birlikte kadastro birimleri de eklenerek kurum Tapu ve Kadastro Genel Müdürlügüune dönüştürülmüştür.

1925 tarih ve 658 sayılı "Kadastro Kanunu"nun yürürlüğe girmesinin ardından 1925 y1lı Mayıs ayından itibaren Ankara, İstanbul, İzmir, Bursa ve Konya'da kadastro çalışmalarına başlanmıştır. Harita Genel Müdürlüğü 1925-1936 yılları arasında Ankara, İstanbul, Kocaeli ve Malatya'da 1/500, 1/1000 ve 1/2000 ölçekli planlar üreterek kadastro çalışmalarına destek olmuştur ${ }^{82}$.

Konu Türkiye Büyük Millet Meclisi'nde de gündeme gelmiş, yapılan şikâyetlere cevap olarak Maliye Bakanı Hasan Bey, tahrir faaliyetleri ile ilgili 128 komisyonun 28 vilâyette çalışmalar yaptığını söylemiştir ${ }^{83}$. Buna rağmen çalışmalar yetersiz bulunarak, mevcut sistemle ülkenin tam tahririnin ancak 50-60 yılda tamamlanabileceği ifade edilmiştir ${ }^{84}$.

1923-1950 yılları arasında 17 vilâyet, 11 kaza, 214 nahiye ve köy ile 21 müstakil çiftlikte şehir kadastrosu yapılmış ve 23.614 gayrımenkulün tapu kütükleri tesis edilmiştii ${ }^{85}$.

Bununla birlikte ülkedeki tapu ve kadastro eksikliğinden kaynaklanan sıkıntılar 1950 y1lına kadar devam etmiş, mahkemelerde önemli iş yükü oluşturmuştur. Özellikle köylerde yaşanan bazı olaylar şu şekilde dile getirilmiştir ${ }^{86}$ : "Mahkemelerdeki davalarımızda ceza ve tevkif evlerindeki mahkûmların çoğu arazi ve tarla işlerindendir. Çünkü tarlaları, bahçeleri, evleri hâlâ üvey kardeşler, amcalar, dedeler, yeğenler elindedir. Mirastır, anlaşamazlar. Hepsi aynı yeri ister. Aynı toprağa sahip olmak ister. Bu yüzden döğüşürler, yaralanırlar, ölürler. Ve sonra da ölenlerle öldürenler arasında yıllarca intikam devam eder. Bu yüzden aileler yıkılır, sefil olur... Bunun için ben tapu ve kadastro işlerinin şehirlerden değil, köylerden, köy sınırlarından başlamasını istiyorum."

\footnotetext{
${ }^{78}$ CHP Meclis Grubu Adına Halim ATEŞALP (Sivas); 44.02.1959, TBMM, TBMM ZC (11.Dönem), Cilt:7, s.668.

${ }^{79}$ Reşit Bey (Malatya); 19.05.1926, TBMM, TBMM ZC (2.Dönem), Cilt:25, s.285.

${ }^{80}$ Ahmet YAŞAYAN - Hüseyin ERKAN - Gökşin SEYLAM; "Kadastro Kavramı ve Türkiye Kadastrosu”, TMMOB Harita ve Kadastro Mühendisleri Odası 13. Türkiye Harita Bilimsel ve Teknik Kurultayı 1822 Nisan 2011, Ankara.

${ }^{81}$ Resmî Cerîde; 2 Mayıs 1925, Say1:99, s.169-171.

${ }^{82}$ Ahmet YAŞAYAN - Hüseyin ERKAN - Gökşin SEYLAM; a.g.makale, TMMOB Harita ve Kadastro Mühendisleri Odası 13. Türkiye Harita Bilimsel ve Teknik Kurultayı 18- 22 Nisan 2011, Ankara.

${ }^{83}$ Maliye Vekili Hasan Bey (Trabzon); 19.05.1926, TBMM, TBMM ZC (2.Dönem), Cilt:25, s.285.

${ }^{84}$ Şükrü Bey (Biga); 19.05.1926, TBMM, TBMM ZC (2.Dönem), Cilt:25, s.286.

${ }^{85}$ Devlet Vekili İzzet AKÇAL (Rize); 24.02.1960, TBMM, TBMM ZC (11.Dönem), Cilt:12, s.378.

${ }^{86}$ Hasene ILGAZ (Çorum); 14.02.1950, TBMM, TBMM TD (8.Dönem), Cilt:24 s.570.
} 


\section{7-Diğer Problemler}

Cumhuriyet idaresinin ortaya koyduğu kanunlarla vatandaşlar arasında hak eşitliği kurulduğu ve önceki dönemlerde, haksızlığa uğradıkları halde o kişiden korktukları için dava açamayan vatandaşların bugün mahkemelerde daha rahat dava açarak haklarını arayabildikleri görülmektedir ${ }^{87}$. Medenî hukuka geçilmekle mahkemelerde fikhın esnetilmesi uygulamalarından ${ }^{88}$; aynı zamanda azınlık hukuku kaldırılıp, medenî kanuna geçilerek kilise ve havraların adalet hizmeti vermelerinden vazgeçilmiştir ${ }^{89}$. Ülkede sosyal nizamın kurulması için kanun hakimiyetinin tesis edilmesi gerektiği ifade edilmiştir ${ }^{90}$. Çünkü bir ülkede hürriyet ve demokrasiyi yaşatacak şeyin adalet olduğ $\mathrm{u}^{91}$, bir ülkede adalet biterse her şeyin biteceği ifade edilmiştir ${ }^{92}$. Bu ikazlara karşılık, dönemin Adalet Bakanı, yapılan düzenlemelerin "İnkılâp Kanunu" olduğunu ve bunların değiştirilmesinin söz konusu olamayacağını ifade etmiştir"

Bununla birlikte adalet mekanizmasının çalışması hakkındaki eksikler de eleştirilmiştir. Toplumda suçlu çocukların sayısının artmaya başladığ ${ }^{94}$, şahitlere ödenen masraf ve yollukların az olduğ ${ }^{95}$, muhtekirlere gereken cezanın verilmediğ ${ }^{96}$ ve davaların uzadığından şikâyet edilmiştir ${ }^{97}$. Adlî yargı törenlerinde siyasî konuşmalar yapıldı $\breve{g}^{98}{ }^{9}$, usûl kanunları millî bünyemize uygun olmadığı için $^{99}$ Medenî Kanun ve Ceza Kanunu'nun uygulanmasında aksaklıklar yaşandı $\breve{g}_{1}{ }^{100}$; hakimlerin teftişlerinde müfettişlerin hangi gazeteyi okudukları veya Halkevine gidip gitmedikleri gibi ideolojik sorular sorduklar1 ${ }^{101}$, yeni emeklilik kanununun, yaş haddini dolduran hakimlerin bakan tarafından istendiği anda emekliye sevk edilebilecek olmasının adlî istiklâli zedeleye bir husus olduğu vurgulanmıştır ${ }^{102}$.

\section{Sonuç}

Türkiye'de hukuk inkılâbı ile birlikte adalet alanında da önemli gelişmeler yaşanmıştır. Zihniyet olarak halkın hükümetten "adalet dilenmesi" şeklindeki mevcut anlayışından, "hükümetler, halkın mal, hayat ve namusunu korumak için teşekkül etmiştir" anlayışına geçilmesi sağlanmıştır. Mevzuat anlamında da yeni bir adalet sistemi geliştirilmiştir.

Fizikî gelişmeler de bunlara paralel bir şekilde gitmiştir. 1924 yılında 99 olan Sulh Hukuk Mahkemesi sayısı, 1927 yılında 235'e çıkartılmış; 1927 yılında 1877 olan hakim sayısı, 1949 yılında 2400'e ulaşmıştır. 1945 yılında ülke sathında 467 adet cezaevinin bulunduğu görülmektedir. Bu binaların çoğu elverişsiz olmakla birlikte, iş esası üzerine kurulmuş, döner sermaye ile çalışan, mahkûmları çalıştırma ve 1slah etme amacıyla yeni sistem cezaevleri de yapılmaya başlanmıştır. Adalet personelinin özlük haklarında iyileştirmeler yapılmış; 1924

\footnotetext{
${ }^{87}$ Adliye Vekili Mahmut Esat Bey (İzmir); 12.04.1927, TBMM, TBMM ZC (2.Dönem), Cilt: 31, s.80.

${ }^{88}$ Besim Atalay Bey (Aksaray); 24.04.1928, TBMM, TBMM ZC (3.Dönem), Cilt: 3, s.230-231.

${ }^{89}$ Adliye Vekili Mahmut Esat Bey (İzmir); 24.04.1928, TBMM, TBMM ZC (3.Dönem), Cilt: 3, s.228-229.

${ }^{90}$ Feyzullah USLU (Manisa); 25.05.1943, TBMM, TBMM ZC (7.Dönem), Cilt: 2, s.223.

${ }^{91}$ Süleyman Sırrı İÇÖZ (Yozgat); 14.02.1950, TBMM, TBMM TD (8.Dönem), Cilt:24, s.578.

${ }^{92}$ Saffet TUNCAY (Siirt); 22.05.1945, TBMM, TBMM TD (7.Dönem), Cilt: 17, s.245.

${ }^{93}$ Adliye Vekili Ali Rıza TÜREL (Konya); 24.05.1944, TBMM, TBMM ZC (7.Dönem), Cilt: 10, s.254.

${ }^{94}$ Tezer TASKIRAN (Kastamonu); 24.05.1944, TBMM, TBMM ZC (7.Dönem), Cilt: 10, s.245.

${ }^{95}$ Sefik TUGAY (İçel); 22.05.1945, TBMM, TBMM TD (7.Dönem), Cilt: 17, s.261.

${ }^{96}$ İbrahim ARVAS (Van); 22.05.1945, TBMM, TBMM TD (7.Dönem), Cilt:17, s.262.

${ }^{97}$ Hulki KARAGÜLLE (Konya); 19.12.1946, TBMM, TBMM TD (8.Dönem), Cilt: 3, s.291.

${ }^{98}$ Osman Nuri KÖNİ (İstanbul); 27.12.1947, TBMM, TBMM TD (8.Dönem), Cilt:8, s.428.

${ }^{99}$ Feyzi KALFAGILL (Diyarbakır); 27.12.1947, TBMM, TBMM TD (8.Dönem), Cilt:8, s.439.

${ }^{100}$ Nazım POROY (Tokat); 23.02.1949, TBMM, TBMM TD (8.Dönem), Cilt:16, s.462.

${ }^{101}$ Hulki KARAGÜLLE (Konya); 27.12.1947, TBMM, TBMM TD (8.Dönem), Cilt:8, s.451.

${ }^{102}$ Hasan DİNÇER (Afyonkarahisar); 14.12.1950, TBMM, TBMM TD (8.Dönem), Cilt: 24, s.563-564.
} 
yılında, Tapu Umum Müdürlüğü kurularak kadastro çalışmaları başlatılmış, böylece toprak anlaşmazlıklarından doğan olayların sayısı azaltılmıştır.

Adliye hizmetlerinde özellikle maddî ve fizikî imkânsızlıklar yüzünden bazı problemler yaşanmışsa da, cumhuriyet idaresi zaman içerisinde bu sıkıntıları en alt seviyelere çekmeye çalışmıştır.

\section{KAYNAKÇA}

\section{1- Türkiye Büyük Millet Meclisi Tutanak Dergisi ve Zabıt Cerideleri}

Türkiye Büyük Millet Meclisi Tutanak Dergisi (8.Dönem), Cilt:3, Ankara, 1947.

Türkiye Büyük Millet Meclisi Tutanak Dergisi (8.Dönem), Cilt:8, Ankara, 1948.

Türkiye Büyük Millet Meclisi Tutanak Dergisi (8.Dönem), Cilt:16, Ankara, 1949.

Türkiye Büyük Millet Meclisi Tutanak Dergisi (7.Dönem), Cilt:17, Ankara, 1945.

Türkiye Büyük Millet Meclisi Tutanak Dergisi (7.Dönem), Cilt:20, Ankara, 1946.

Türkiye Büyük Millet Meclisi Tutanak Dergisi (8.Dönem), Cilt:24, Ankara, 1949.

Türkiye Büyük Millet Meclisi Zabıt Ceridesi (1.Dönem), Cilt:1, Ankara, 1959.

Türkiye Büyük Millet Meclisi Zabıt Ceridesi (2.Dönem), Cilt:6, Ankara,1968.

Türkiye Büyük Millet Meclisi Zabıt Ceridesi (2.Dönem), Cilt:25, Ankara.

Türkiye Büyük Millet Meclisi Zabıt Ceridesi (2.Dönem), Cilt:31, Ankara.

Türkiye Büyük Millet Meclisi Zabıt Ceridesi (3.Dönem), Cilt:3, Ankara.

Türkiye Büyük Millet Meclisi Zabıt Ceridesi (4.Dönem), Cilt:9, Ankara, 1932.

Türkiye Büyük Millet Meclisi Zabıt Ceridesi (5.Dönem), Cilt:11, Ankara, 1936.

Türkiye Büyük Millet Meclisi Zabıt Ceridesi (5.Dönem), Cilt:18, Ankara, 1937.

Türkiye Büyük Millet Meclisi Zabıt Ceridesi (5.Dönem), Cilt:25, Ankara, 1938.

Türkiye Büyük Millet Meclisi Zabıt Ceridesi (6.Dönem), Cilt:18, Ankara, 1941.

Türkiye Büyük Millet Meclisi Zabıt Ceridesi (7.Dönem), Cilt:2, Ankara, 1943.

Türkiye Büyük Millet Meclisi Zabıt Ceridesi (7.Dönem), Cilt:10, Ankara, 1944.

Türkiye Büyük Millet Meclisi Zabıt Ceridesi (7.Dönem), Cilt:12, Ankara, 1944.

Türkiye Büyük Millet Meclisi Zabıt Ceridesi (11.Dönem), Cilt:7, Ankara.

Türkiye Büyük Millet Meclisi Zabıt Ceridesi (11.Dönem), Cilt:12, Ankara, 1960.

\section{2- Diğer Eserler}

Atatürk ve Türkiye Cumhuriyeti Tarihi (Editör:M. Derviş KILIÇKAYA), Siyasal

Kitabevi, Ankara, 2005.

Hükümetler ve Programları I.Cilt 1920-1960, Türkiye Büyük Millet Meclisi Yayını, Ankara, 1988.

Resmî Cerîde; 2 Mayıs 1925, Say1:99. 
SEMIZ, Yaşar; "1923-1950 Döneminde Türkiye'de Nüfusu Arttırma Gayretleri ve Mecburî Evlendirme Kanunu (Bekârlık vergisi)", Selçuk Üniversitesi Türkiyat Araştırmaları Enstitüsü Dergisi, Sayı:27 (2010), s.423- 469.

T.C. Resmî Gazete, 30 May1s 1942, Say1:5119.

Türkiye Cumhuriyeti Tarihi II, Atatürk Araştırma Merkezi Yayını, Ankara, 2004. YAŞAYAN, Ahmet - Hüseyin ERKAN - Gökşin SEYLAM; "Kadastro Kavramı ve Türkiye Kadastrosu", TMMOB Harita ve Kadastro Mühendisleri Odasl 13. Türkiye Harita Bilimsel ve Teknik Kurultayl, 18-22 Nisan 2011, Ankara. 